\title{
UNEMPLOYMENT AND SECTORAL COMPETITIVENESS IN SOUTHERN EUROPEAN UNION COUNTRIES. FACTS AND POLICY IMPLICATIONS
}

\author{
Gina Cristina DIMIAN ${ }^{1}$, Mirela Ionela ACELEANU ${ }^{2}$, Bogdan Vasile ILEANU ${ }^{1}$, \\ Andreea Claudia ȘERBAN ${ }^{2}$ \\ ${ }^{1}$ Department of Statistics and Econometrics, Faculty of Economic Cybernetics, \\ Statistics and Informatics, Bucharest University of Economic Studies, 15-17, \\ Calea Dorobanti, District 1, Bucharest, 010552, Romania \\ ${ }^{2}$ Department of Economics and Economic Policy, Faculty of Theoretical and Applied Economics, \\ Bucharest University of Economic Studies, 6, Romana Square, \\ District 1, Bucharest, 010374, Romania
}

Received 10 June 2017; accepted 16 August 2018

\begin{abstract}
This article addresses the problem of the main factors driving sectoral unemployment in the Mediterranean countries most affected by this phenomenon. The choice of the four countries (Greece, Italy, Spain and Portugal) relies on the fact that they are dealing with the highest unemployment rates in the European Union and a certain typology of the economic structure. The originality of our research is offered by its direction, less tackled until now, namely the focus on the particularities of the economic sectors, trying to capture differences between them. The importance and the impact of the results are supported by the methods used to produce them, indicators and econometric models that are on trend and bring extra information to available studies. Descriptive statistics and mismatch indexes are used to outline the economic and labour market structure, while the econometric models built on panel data capture the impact of factors such as GVA growth, specialization and labour market mismatches on the unemployment rate at six economic sectors level. Our paper makes three contributions to the literature. First, we have demonstrated that agriculture is the sector of activity less sensitive to output fluctuations in terms of unemployment and can become a buffer for the jobless in times of recessions. Second, we have proved that industry, as a whole, is highly responsive to economic developments and bad specialization could worsen unemployment situation in this sector. Third, we showed that educational mismatches have a significant impact on unemployment in those sectors of activity that employ low educated workforce.
\end{abstract}

Keywords: unemployment, GVA growth, mismatches, economic sectors, panel data analysis, Okun's law.

JEL Classification: E24, C23, J08.

*Corresponding author. E-mail: andre_serban@yahoo.com 


\section{Introduction}

The purpose of this article is to study unemployment problem in four Mediterranean countries (Greece, Italy, Spain and Portugal), most affected by this phenomenon. Our aim is to identify both economic weaknesses that have led to this situation and those sectors that could provide opportunities for sustainable economic growth and for reducing the unemployment rate. The analysis concerns the last twenty three years (1995-2017), a time of great contrasting economic transformations, of economic growth as well as severe recession.

Thus, in the aftermath of the great recession (2008-2010), all the four countries experienced oscillating real output changes that ranged from an average of $-4 \%$ in Greece to nearly $-2 \%$ in Spain and Portugal (Eurostat, 2018). Public deficit climbed to record levels (on average between 12 and 9\% of GDP) except for Italy where it averaged 4\%. General government gross debt exceeded the value of GDP in Greece and Italy, while in Spain slightly surpassed $50 \%$ (Eurostat, 2018). More than that, the pace of economic reforms slowed down in these countries because of the crisis (Paciello, 2010).

Direct investment recorded low percentages of GDP in Greece and Italy (less than 20\%), whereas exports were lower than the Eurozone average, ranging from $22 \%$ in Greece to almost 30\% in Portugal. Instead, household consumption expenditure (\% of GDP) has been much higher compared to the Eurozone average, ranging from almost $70 \%$ in Greece to approximately 57\% in Spain (Eurostat, 2018).

Scientists are increasingly talking about 'the polarization of jobs and wealth (Garibaldi \& Taddei, 2013) or 'skill deterioration and social exclusions' (ILO, 2014a, 2014b, 2014c). As an example, in the four Mediterranean countries in our sample, wealth is owned, in proportions that ranged between almost 52\% in Portugal and 39\% in Greece, by the top $10 \%$ of the population (OECD Statistics, 2018).

The poor labour market performance even before the recent crisis has led to a sharp deterioration of workers' situation and social conditions afterwards. Total unemployment rate has quickly become twice as high in Greece and Spain, compared to Eurozone average. In Italy, youth unemployment rate was three times higher than total unemployment rate, getting to talk about 'the youth - old age dualism' or 'intergenerational conflict' (Garibaldi \& Taddei, 2013; Eichhorst \& Neder, 2014; Di Pietro \& Urwin, 2006). In the years following the financial crisis, in Greece, long term unemployment rate has surpassed, on average, $10 \%$. Of these people $70 \%$ were unemployed for over 1 year and $50 \%$ for over two years, a situation that led both to 'skill deterioration and social exclusions' (ILO, 2014a). Unemployment disparities were mainly driven by regional-level equilibrium and the inefficiency of labour market institutions (Rios, 2016; Gabrisch \& Bruscher, 2006).

Employment rate remained low in three of the Mediterranean countries in our sample, except for Portugal, which reached Eurozone average of 64\%. Employment distribution by sectors shows a mixed picture: high percentage of the population working in agriculture in Greece and Portugal, the share of the population employed in industry in Italy over the Eurozone average and lower shares of the population employed in services in Portugal.

In Spain there is talk of a crisis of employment driven mainly by the contraction of the construction sector (ILO, 2014b). 
The deterioration of social conditions may be due to a wider use of temporary contracts. Another common feature of the four countries, which can largely explain the situation of their labour markets, is the low level of education of the population compared to the Eurozone average. For example, in Portugal and Spain, the shares of the population aged 16 to 64 , who completed at least upper secondary and post-secondary non-tertiary education, were half the Eurozone average in the years following the financial crisis: 20.9 and $23.6 \%$, compared to $43.2 \%$ (Eurostat, 2018).

This problem of the relatively low level of education is accompanied by a severe skills mismatch (Patrizia \& Giuseppe, 2015; Matuzeviciute, Butkus, \& Karaliute, 2017) and for some of the countries in our sample, such as Greece and Portugal, by emigration of the young people, highly educated and qualified (Suciu \& Florea, 2017).

Another explanation for the high unemployment rates in these countries can be represented by the large share of people employed in small and medium enterprises, knowing that these companies find it more difficult to ensure a high quality and stability of jobs during fluctuations in economy (Ghita, Saseanu, Gogonea, \& Huidumac, 2018). In addition, policies aimed at improving labour market conditions have had a relatively low financial support: $0.822 \%$ in Greece and $1.693 \%$ in Italy, compared to $3.438 \%$ of GDP in Spain (Eurostat, 2018).

In terms of the sectors that can offer comparative advantages and a source for sustainable economic growth, all four countries can take advantage of the opportunity offered by tourism and the development of a so-called agri food sector (ILO, 2014c).

Starting from this overall picture of the economies of the four Mediterranean countries presented in the introduction, this article focuses on the functioning of their sectors of activity (descriptive statistics) and on the influence of GVA growth and some other relevant labour market indicators on unemployment rate, in order to identify the long and short time relationships between these variables (panel data analysis).

The rest of our paper is organised as follows: Literature review, in which the focus is on the models that have studied hysteresis hypothesis in unemployment and the relationship between unemployment and economic growth, as a starting point to study the driving factors of the unemployment rate; Data and methods, summarizing relevant aspects related to the indicators and econometric models to be applied in order to assess the relationship between sectoral unemployment rates and possible determinants; Results, detailing the outcomes of the statistical and econometric methods; Conclusions, which are concentrated on the most important results of the study conducted and possible lines of action that could be applied to improve the existing situation of the labour market.

\section{Literature review}

Unemployment remains even nowadays one of the most appealing topics for researchers mostly because the recent crisis seems to have lasting effects on labour market and its efficient functioning. In this regard, Furceri and Mourougane (2012) demonstrated that "downturns have, on average, a positive impact on the level of structural unemployment rate" but this impact varies with the severity of the crisis. Moreover, Van Ours (2015) and Canon, Chen and Marifian (2013) showed that "some labour markets are more vulnerable to fluctuations 
in economic growth than others" just like some age groups are more affected by the recession than others.

Recently, the focus has been on testing hysteresis hypothesis, identifying the driving factors of unemployment and measuring the relationship with other important macroeconomic variables, such as GDP growth and inflation.

Within this context, the most common question is whether 'cyclical fluctuations will have permanent effect on the level of unemployment rate' (Tatoglu, 2011) or if the hysteresis hypothesis in unemployment is supported by the data or not. The results of the studies are rather divergent depending on many factors: the time period under the study, countries in the sample and econometric techniques applied.

Camarero, Carrion-i-Silvestre, and Tamarit (2006), for example, propose three types of tests in order to verify the hysteresis hypothesis in unemployment in OECD countries: 'classical' tests for unit roots in unemployment in a panel context: Im and Lee (2001), Im, Pesaran, and Shin (1997, 2003), Maddala and Wu (1999) and Hadri (2000); tests for unit roots that allow for multiple structural changes: Carrion-i-Silvestre, del Barrio, and López (2002); all the previous tests applied taking into account the cross-sectional dependence.

The results of these last tests have rejected the hysteresis hypothesis, contrary to other previous studies. The authors suggest that the structuralist theory of Phelps (1998) applies in this case, i.e. 'the majority of shocks to unemployment are temporary but, occasionally, and mainly associated with recessions, can provoke a change in the level of the natural rate of unemployment' (Camarero et al., 2006).

Bolat, Tiwari, and Erdayi (2014) and Khraief, Shahbaz, Heshmati, and Azam (2015) have confirmed this theory for the OECD countries, when they have applied nonlinear unit root tests. The hysteresis hypothesis in unemployment is strongly rejected when structural changes and cross-section dependence are taken into consideration.

Syssoyeva-Masson and Andrade (2017), studying the hysteresis hypothesis in PIIGS countries and the period 1960-2014, concluded that this hypothesis is confirmed for all the countries under the study, but there is no reason to treat them as a group in terms of macroeconomic performances.

Studying the same countries and almost the same period (1960-2011), Li, Ranjbar, and Chang (2017) have shown that the aforementioned hypothesis can be demonstrated only in the case of Greece, when the methodology relies on sharp and smooth breaks. When the Fourier unit root test was applied, Cheng, Wu, and Chang (2014) found that hysteresis hypothesis in unemployment holds for PIIGS countries, except Portugal and Spain. In the case of the last country, Garcia-Cintado et al. (2015) tested the hysteresis hypothesis in 17 Spanish regions (1976-2014) using a large battery of univariate unit root tests and the results supported the hysteresis hypothesis for all regions. Based on these results, the authors recommended policy intervention to reduce the sluggishness in the labour market adjustment to the adverse shocks.

Taking into consideration the relationship between economic growth and unemployment, a number of authors have applied econometric models based on Okun's law in order to determine the growth rate required to balance unemployment (Perman, Gaetan, \& Tavera, 2013; Dinu, Marinas, Socol, \& Socol, 2011). 
Van Ours (2015), for example, notes that the recent economic downturn has resulted in an 'unprecedented' reduction of the rate of economic growth, but the unemployment rate has decreased comparable to that in the previous crisis of the $80 \mathrm{~s}$. The author has revealed that to keep the unemployment rate steady an economic growth rate of $2.4 \%$ is required and he has concluded that boosting economic growth seems to be the general solution of the major problems remaining after the end of the recession.

Hooper (2017) investigating Okun's Law in 185 countries around the world demonstrates that there is a robust relationship between unemployment and economic growth. His results strongly support Okun's Law: that a $1 \%$ drop in unemployment leads to a $1-4 \%$ increase in growth, across the globe. Moreover, Azorin and De la Vega (2017) using Verdoorn and Okun coefficients, show that the output growth required for a rise in employment is well below the level necessary to reduce the unemployment rate.

As regards, the four Mediterranean countries analysed in this paper, Dritsaki and Dritsakis (2009) tested and confirmed the significance of the Okun's Law in all countries, except for Greece, the relationship proving to be stronger in the case of Italy.

Villaverde and Maza $(2007,2009)$ revealed that Okun's law is valid for Spain as a whole, but there is a certain dualism at regional level, largely explained by differences in productivity. The main results point to the regional segmentation and, as a consequence, the duality of the solutions necessary to be applied in order to diminish unemployment: measures to stimulate economic growth in regions where unemployment is highly dependent on economic growth rate and targeted measures to increase employment and reduce unemployment (fiscal, institutional or informational) in the others.

Apergis and Rezitis (2003) estimated Okun coefficients for a number of Greek regions during the period 1960-1997 and concluded that there are not major differences except for two of them: Epirus and North Aegean Islands. Especially in the case of the latter and because Greece has shown a higher unemployment rate dependence on output growth since 1981, the aforementioned authors recommended stronger deregulation policies of the economic sectors.

In the same vein, but for another period 2000-2012, Karfakis, Katrakilidis, and Tsanana (2014) estimated a dynamic forecasting model. The results have shown that the response of the unemployment rate to output fluctuations is more exacerbated in recession periods and in the case of Greece reducing unemployment rates implies note only measures that foster aggregate demand but also measures of structural nature (Christopoulos, 2004).

Zanin (2018) investigates Okun's law in Italy using two measures of the unemployment rate: a traditional one based on a labour force with and without work experience and a new one restricted to the labour force with experience. The author shows that, in this country, the young population is less sensitive to business cycles. For the same country, but at regional level, Busetta and Corso (2012) examined Okun's law taking into consideration that an asymmetric relation between GDP and unemployment rate can appear. In addition, the authors tested the relationship between economic growth and employment rate including among regressors, besides economic growth rate, labour productivity and time flexibility. They concluded that in Italy, unemployment rate depends to a lesser extent than employment rate on economic growth fluctuations showing a more structural than cyclical nature. 
Moreover, it seems that periods of economic expansion have significantly more impact on the labour market than recessions, being evidence for the presence of positive asymmetry (Busetta \& Corso, 2012).

Regarding Portugal, Maria (2016) demonstrated the existence of structural weaknesses that have affected the capacity of this country to adapt to crisis conditions. Using a Q model (based on rational expectations, unobserved components and stochastic shocks) the author showed that in the period 2008-2012, the country experienced significant changes in terms of overall economic results and those of the labour market.

Apart from output fluctuations as one of the main drivers of unemployment dynamics, recent studies have also pointed to a variety of other conditions that influence the level and composition of unemployment: intersectoral and interregional labour reallocations (Garonna \& Sica, 2000), labour mobility (Mitra \& Ranjan, 2010), sectoral composition of economic activity (Ezcurra, 2011), general education (Hall, 2016), specialized skills (Ortego-Marti, 2017), unemployment benefits (Zhang, 2017), government purchases (Holden \& Sparrman, 2017).

\section{Data and methods}

The purpose of the empirical analysis is twofold: to examine the economic and labour market structure in the four Mediterranean countries in our sample in order to capture changes over time and how the recession has influenced the functioning of their sectors (descriptive statistics) and to study the influence of GVA growth and some other relevant labour market indicators on sectoral unemployment rate, in order to identify the long and short time relationships between these variables (panel data analysis).

The main variables are: Gross Value-Added (GVA), measured as growth rate or natural logs and unemployment rate (UR) measured in percentages. The first variable has been computed using data taken from EUROSTAT and the second from ILOSTAT Database. They cover a period of 23 years (1995-2017) and six economic sectors (Agriculture-AGR, Manufacturing-MAN, Mining and quarrying; Electricity, gas and water supply-MIN, Construction-CONSTR, Trade, Transportation, Accommodation and Food, and Business and Administrative Services-TRADE, Public Administration, Community, Social and other Services and Activities-ADM).

Taking into account the fact that, over the last 15-20 years, each of the countries in our sample has experienced structural transformation and its impact on labour market functioning has been less tackled in the recent literature, we thought it would be of interest to include in the analysis an indicator of sectoral specialization. Thus, the degree of specialization of each economy has been quantified by means of Krugman specialization index (KSI), based on gross value added in the above-mentioned sectors during the period 1995-2017 (Table 1). In this sense, Mongelli, Dorrucci, Ioannou, and Terzi (2015) showed that it is important to distinguish between bad and good specialization and that in some euro area countries frictions play an important role in explaining bad specialization.

Labour market frictions explain why in some countries high levels of unemployment rates coexist with high vacancy rates. With a view to measure their impact on unemployment rates, educational mismatch indexes have been computed and analysed (Table 1). 
Table 1. Variables description and data sources

\begin{tabular}{|c|c|c|}
\hline Variables & Description & Data sources \\
\hline $\begin{array}{l}\text { Krugman } \\
\text { Concentration } \\
\text { Index (KSI) }\end{array}$ & $\begin{array}{l}\text { KSI is a measure of 'relative specialization compared } \\
\text { with a benchmark' (ECB, 2004). In our paper, the } \\
\text { benchmark is represented by the group of four coun- } \\
\text { tries mean. This index can take values between } 0 \text { and } \\
2 . \text { A value of } 0 \text { or near } 0 \text { means that respective coun- } \\
\text { try is not specialized in a specific industry, has the } \\
\text { same structure with the group. A value of } 2 \text { or close } \\
\text { to } 2 \text { implies a strong specialization, i.e. the country } \\
\text { has a completely different structure compared to the } \\
\text { group. } \\
K_{k}(t)=\sum_{i}\left|V_{k}^{i}(t)-\bar{V}^{i}(t)\right| \text {, } \\
\text { where } V \text { represents the sector's } i \text { share of GVA in } \\
\text { total, for country } k \text { at time } t \text { and } \bar{V} \text { refers to the } \\
\text { group of countries from which } k \text { has been excluded } \\
\text { (ECB, 2004). }\end{array}$ & $\begin{array}{l}\text { EUROSTAT Database, } \\
\text { National Accounts, } \\
\text { National Accounts aggre- } \\
\text { gates by industry (up to } \\
\text { NACE } A^{\star} 64 \text { ) }\end{array}$ \\
\hline $\begin{array}{l}\text { Educational } \\
\text { Mismatch Index } \\
\text { (EMI) }\end{array}$ & $\begin{array}{l}\text { EMI has been computed as a measure of the gap } \\
\text { between the share of the educational group } i \text { in } \\
\text { employment }\left(n_{i}\right) \text { and the same share in total work- } \\
\text { ing age population }\left(q_{i}\right) \text {, weighted with the category } \\
i \text { share in working age population }\left(q_{i}\right) \text { (COMM, } \\
\text { 2013). } \\
E M I=\sum_{1=1}^{n} q_{i} \cdot\left|q_{i}-n_{i}\right|\end{array}$ & $\begin{array}{l}\text { ILOSTAT Database, } \\
\text { Working-age population } \\
\text { by sex, age and education; } \\
\text { Employment by sex, age } \\
\text { and education. }\end{array}$ \\
\hline
\end{tabular}

The most suitable econometric techniques for causality analysis are sensitive to the specific features of the available series, such as: the presence of the trend, periodical oscillations due to seasonality and/or cyclicity, the presence of outliers, stationarity, etc. In order to select the appropriate techniques to be applied for estimating the models, we have performed a set of investigations, grouped as time series analysis and panel data analysis.

I. Time series analysis:

- A structural break-analysis.

Before performing the unit root tests necessary to establish the order of integration we have searched for identification of possible structural breaks. We have specified the classical regression trend model:

$G V A \_G R(t)=a+b t+u$ or ln_GVA(t)=a+bt+u and $U R(t)=d+e t+w$, where $t$ denotes the time period, here the year, $a, b, d, e$ are the regression coefficients and $u$ and $w$ disturbances assumed as white noises, estimated with OLS. We then, have searched for structural breaks using the CUSUM of Square Test (Turner, 2010). We have repeated the procedure for KSI and EMI indicators.

- Unit root analysis of the economic indicators.

In the literature there is evidence that classical unit root tests such as DF, Augmented Dickey-Fuller (ADF) or Phillips-Perron (PP) are obsolete mainly because their results are biased in the case of the existence of autocorrelation and or heteroskedasticity, as it is the case of DF and partially the case of ADF. The Elliott-Rothenberg-Stock (ERS) seems to be 
more powerful (Eliott, Rothenberg, \& Stock, 1996; Dickey \& Fuller, 1979; Enders \& Lee, 2012; Perron \& Vogelsang, 1992).

Moreover none of the above mentioned tests is strongly affected by the presence of time series breaks (Choi, 2015). In order to avoid this kind of problem and taking into account the available relatively short time series $(\mathrm{T}<25)$ we have chosen to apply Vogelsang $(\mathrm{min}-\mathrm{t})$ breaks unit root test (Vogelsang \& Perron, 1998). The new generation of tests such as Narayan (Narayan \& Popp, 2010), HLT (Harvey et al., 2013), Furuoka $(2014,2017)$ etc. are still under debate regarding the problem of their power of prediction. Another thing which should be also counted is that in short time series, like in this case, introducing more variables and/or restrictions implies again the reduction of the power of the tests due to the loss of degrees of freedom.

The results of the time series analysis are concisely presented in the next section and detailed in the Appendix.

II. Panel Data Analysis consisted of the following steps: verifying once again the stationarity of the data series, in the panel framework, and the order of integration. Since we have noticed the presence of the breaks in different situations in the previous analysis combined with the fact that the time-period is not very long the results of the unit root tests in the level proved to raise some questions. Therefore, we considered that the results of the tests in the first differences are more reliable. We also needed to take into account that some series may be nearly I(1). Since a classical approach consisting of Panel Vector Auto Regressive (PVAR) or Panel Error Correction Model (PECM) could not be the best solution, a widely used less restrictive method has been applied - the Panel Autoregressive Distributed Lag (PARDL). Here a mix of $\mathrm{I}(0)$ and $\mathrm{I}(1)$ but none $\mathrm{I}(2)$ variables are permitted and the method allows to study both long-run and short run relations (Im et al., 1997). We also avoided to introduce as exogenous two variables potentially cointegrated (here EMI and KSI) in order to comply with the conditions imposed by Pesaran and Shin (1999).

Following the work of Huang and Yeh (2013) we have started from a general ARDL model in which the unemployment rates in the four countries are explained by GVA growth rates at time $t$ to $t-j$ and the past values of the dependent variable:

$$
\Delta U R_{i t}=\mu_{i}+\phi_{i} U R_{i, t-1}+\beta_{i}^{\prime} \ln _{-} G V A_{i t}+\sum_{j=1}^{p-1} \lambda_{i j}^{*} \Delta U R_{i, t-j}+\sum_{j=0}^{q-1} \delta_{i j}^{*} \Delta \ln \_G V A_{i, t-j}+\varepsilon_{i t},
$$

where $\phi_{i}=-\left(1-\sum_{j=1}^{p} \lambda_{i j}\right), \beta_{i}=\sum_{j=0}^{q} \delta_{i j}, \lambda_{i j}^{*}=-\sum_{m=j+1}^{p} \lambda_{i m}$ and $\delta_{i j}^{*}=-\sum_{m=j+1}^{q} \delta_{i m}$.

In particular, the long run unemployment rate function is given by:

$$
U R_{i t}=\theta_{0 i}+\theta_{1 i} \ln \_G V A_{i t}+u_{i t} .
$$

In a particular case, in the ECM model we included the trend component in the longrun equation.

The ARDL $(1,1)$ equation is:

$$
U R_{i t}=\alpha_{i}+\lambda_{i} U R_{i, t-1}+\delta_{1 i} \ln \_G V A_{i t}+\delta_{2 i} \ln \_G V A_{i, t-1}+\varepsilon_{i t} .
$$


The error correction equation is:

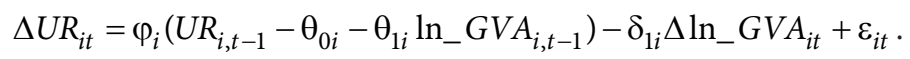

As a novelty, compared with the above listed model we introduced the EMI or KSI as causes in both long-run and or short run equations.

In order to capture the effects of the crisis and thus to take into consideration the presence of structural changes we defined several dummy variables called DUM, in general like:

$$
\operatorname{Dum}=\left\{\begin{array}{l}
1, \text { if } t \geq 2008 \\
0, \text { if } t<2008
\end{array}\right\} \text {, where } \mathrm{t}=1995 \text { to } 2017 .
$$

For Public Administration sector we used a dummy defined like Dum $=\left\{\begin{array}{l}1, \text { if } t \geq 2009 \\ 0, \text { if } t<2009\end{array}\right\}$.

In order to achieve a better fit for the model, a particular dummy was created for Agriculture sector, where we used a panel Dummy(i,t) (Table 2) defined like:

Table 2. Dummy variable for agriculture

\begin{tabular}{|c|c|c|c|c|}
\hline tlcountry & Greece & Italy & Spain & Portugal \\
\hline 1995 & 0 & 0 & 0 & 0 \\
\hline 1996 & 0 & 0 & 0 & 0 \\
\hline$\ldots$ & $\ldots$ & $\ldots$ & $\ldots$ & $\ldots$ \\
\hline 2004 & 0 & 0 & 0 & 1 \\
\hline 2005 & 0 & 0 & 0 & 1 \\
\hline 2006 & 1 & 1 & 0 & 1 \\
\hline 2007 & 1 & 1 & 0 & 1 \\
\hline 2008 & 1 & 1 & 0 & 1 \\
\hline 2009 & 1 & 1 & 0 & 1 \\
\hline 2010 & 1 & 1 & 1 & $\ldots$ \\
\hline$\ldots \ldots$ & $\ldots$ & $\ldots$ & 1 & \\
\hline 2017 & 1 & 1 & & \\
\hline
\end{tabular}

The results of the empirical analysis are subject of chapter 3.

\section{Results}

The main objective of this paper was to study long and short-term relationships between unemployment rate and potential factors of influence.

The analysis of the general economic situation has demonstrated that the unfavourable context in which the labour markets of the four countries function is due to several factors, including: a poor structure of economy (low representation of industry and poor performances of primary and tertiary sectors), mismatch between the results of the education system and labour market needs, strong dependence on the economic cycle. 
We have computed two statistical indexes, Krugman specialization index (KSI) and Educational mismatch index (EMI), in order to study in greater detail, the above mentioned features. Indexes calculated with a view to capturing differences between the level of education of the population and the level needed to respond to labour market requirements indicate Italy as a country with large imbalances and the other Mediterranean countries with growing mismatch.

Krugman specialization index has demonstrated that the four countries can be grouped in two categories: countries with low and decreasing specialization: Greece, Italy and Portugal and a country with relatively high and growing specialization: Spain.

With the aim of selecting the most appropriate econometric techniques for causal analysis, we have performed a set of preliminary investigations on our time variables.

We will synthetically provide henceforth the results by sector, country and main indicators (gross value added growth and unemployment rate). Unit root analysis, both for time series and panel data, is detailed in Appendix.

\subsection{Agriculture (AGR)}

The preliminary time series analysis of the main indicators has suggested that, gross value added, measured in logs, (ln_GVA) has a linear trend in the case of Greece and Spain and seems to be stationary with regard to Portugal and Italy. In terms of unemployment rate (UR), positive or negative trends are visible for Spain and Italy. For all 4 countries, there is evidence of trend changes after the breaks and also changes in the intercept.

Cusum of Squares test points to the fact that the variables ln_GVA and UR exhibit in almost all of the countries a break before the economic crisis (Figure 1).

The group of the four countries shares both commune and different characteristics of the economic indicators considered here. The time series in our sample have a small dimension and in this case a panel-approach, and thus a larger sample, may increase the quality of the econometric methods applied. From an economic point of view, the four countries, all member of EU, are treated frequently as a group, for many reasons described in the beginning of this paper, so again appealing to panel analysis become more desirable.

Before selecting the appropriate method of analysis, we have studied the panel unit root just to confirm the results achieved in the time series analysis. On the other hand, we have already saw that in the pre-crisis period and crisis period, 2002-2008 we have many changes in intercept or/and trend in many variables.

The panel-unit root tests have confirmed, in general, the results of the time-series analysis. In terms of agriculture we have a mix of I (0) and I (1) variables (Appendix). In this case we have applied ARDL technique in order to estimate the long and short-run relationships between the variables of interest.

The economic development seems to have a weak and questionable impact on the unemployment change in this sector of activity. The three ARDL models reveal significant and negative coefficients for the long-run ln_GVA and cointegration terms but non-statistically significant for ln_GVA in the short run equation. Both KSI and EMI found to have independently statistically significant impact of unemployment change on the long term (Table 3). 
Greece
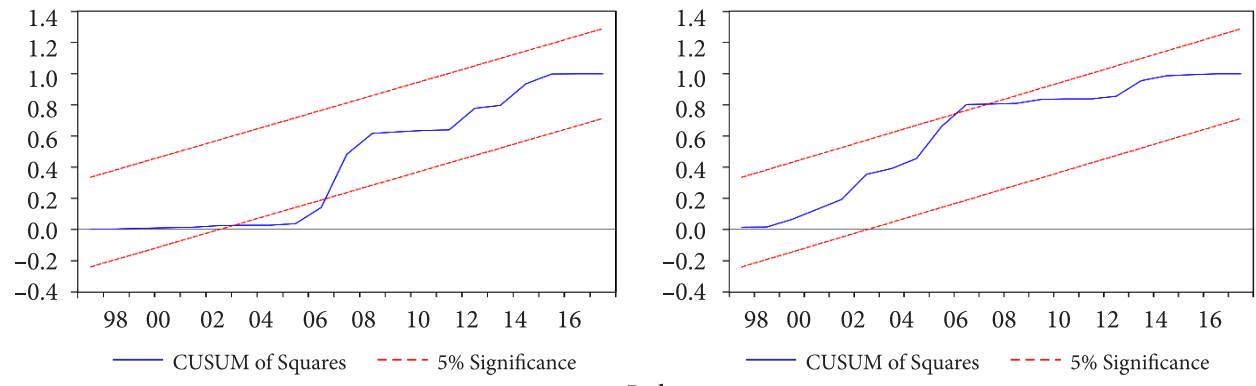

Italy
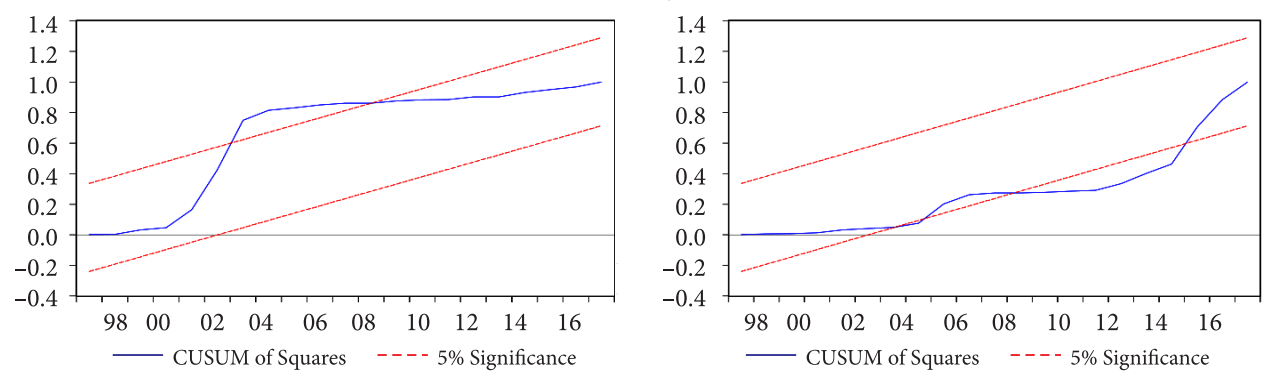

Portugal
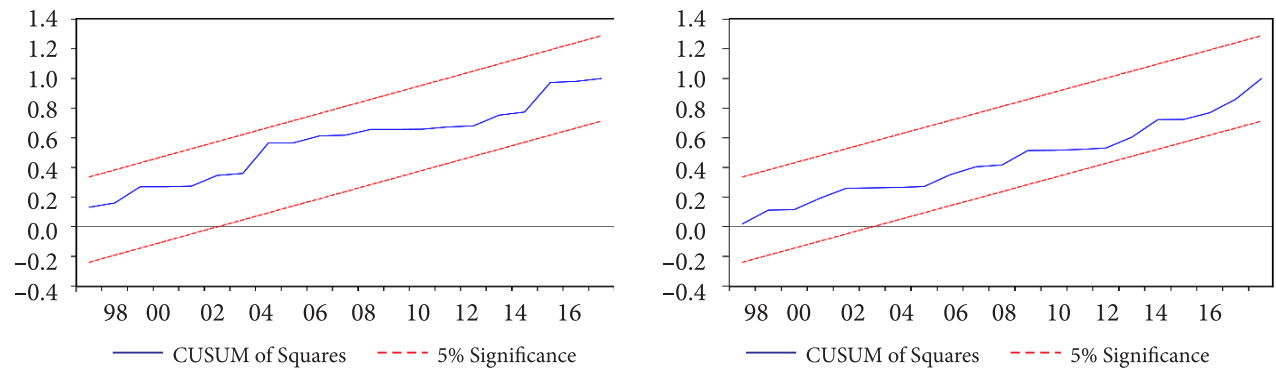

Spain
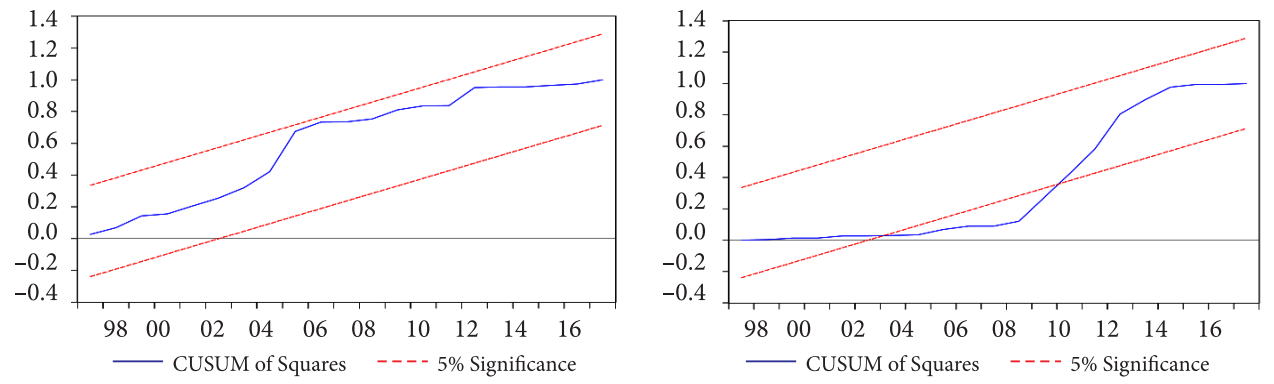

Figure 1. Testing the presence of breaks in ln_GVA (left) and UR (right) 
Table 3. Panel Data Analysis results for Agriculture (AGR)

\begin{tabular}{|c|c|c|c|}
\hline Variables & Model 1 (ARDL $(1,1,1)$ & $\begin{array}{c}\text { Model } 2(\operatorname{ARDL}(1,1,1) \\
\text { EMI included }\end{array}$ & $\begin{array}{c}\text { Model } 3 \text { (ARDL }(1,1,1) \\
\text { KSI included }\end{array}$ \\
\hline \multicolumn{4}{|l|}{ Long run } \\
\hline Ln_GVA & $-0.069^{\star *}$ & $-0.228^{*}$ & $-0.112^{\star * *}$ \\
\hline KSI & & & $-8.174^{\star *}$ \\
\hline EMI & & $-0.715^{\star \star}$ & \\
\hline \multicolumn{4}{|l|}{ Short run eq } \\
\hline Cointeq & $-0.389^{\star *}$ & $-0.232^{\star *}$ & $-0.421^{\star *}$ \\
\hline$\Delta\left(\ln \_\right.$GVA $)$ & $-0.123^{\star}$ & -0.144 & -0.111 \\
\hline$\Delta(\mathrm{KSI})$ & - & & 18.735 \\
\hline$\Delta(\mathrm{EMI})$ & - & -0.136 & 0.635 \\
\hline c & $1.874^{\star * *}$ & $4.822^{\star * *}$ & $3.530^{* * *}$ \\
\hline Dummy & 0.064 & 0.248 & 0.012 \\
\hline
\end{tabular}

Note: coefficient is significant at level: ${ }^{* *}$ lower than $1 \% ;{ }^{* *} 1-5 \% ;{ }^{*} 6-10 \%$.

\subsection{Manufacturing (MAN)}

In manufacturing, UR and ln_GVA have shown linear trends and an occurrence of breaks in almost all countries and variables, excepting ln_GVA. This result has been also validated by the Cusum of Squares test and unit root tests applied on the time series of each country and indicators (Appendix).

Combining time series analysis results with those from panel unit root analysis, we have concluded that ln_GVA may be assumed to be I(0) on the sample period and all other variables UR, EMI and KSI to be I(1). In this case we have applied the ARDL modelling to measure the impact of the above-mentioned factors on UR dynamics (Table 4).

Table 4. Panel Data Analysis results for Manufacturing (MAN)

\begin{tabular}{|l|c|c|}
\hline \multicolumn{1}{|c|}{ Variables } & $\begin{array}{c}\text { Model 1 (ARDL(1,1,1) } \\
\text { EMI included }\end{array}$ & $\begin{array}{c}\text { Model 2 (ARDL(1,1,1) } \\
\text { KSI included }\end{array}$ \\
\hline \multicolumn{3}{|c|}{ Dependent variable: $\Delta$ UR } \\
\hline Long run & $-18.68^{* * *}$ & $-18.65^{* * *}$ \\
\hline Ln_GVA & & -17.06 \\
\hline KSI & $-0.86^{* *}$ & $-\mathbf{0 . 4 0 ^ { * * }}$ \\
\hline EMI & $-\mathbf{0 . 4 1 ^ { * * * }}$ & $-15.33^{* *}$ \\
\hline Short run eq & $-10.66^{* *}$ & $-33.21^{* * *}$ \\
\hline Cointeq term & & $1.68^{* * *}$ \\
\hline$\Delta$ (ln_GVA) & $1.57^{* * *}$ & $87.38^{* * *}$ \\
\hline$\Delta$ (KSI) & $1.80^{* * *}$ & \\
\hline$\Delta$ (EMI) & $91.25^{* *}$ & \\
\hline Dummy & & \\
\hline C & & \\
\hline
\end{tabular}

Note: coefficient is significant at level: ${ }^{* *}$ lower than $1 \% ;{ }^{* *} 1-5 \% ;{ }^{*} 6-10 \%$. 
In line with the economic theory, the analysis of the results achieved after that two ARDL $(1,1,1)$ models were run, reveals that in the Manufacturing sector GVA growth has a positive impact on UR dynamics (i.e. reducing unemployment rate), on both short and long-term. On the other hand, we may assert that in the analysed activity, specialization has a significant impact on UR changes on the short-run, while the educational mismatches both on short and long-run.

\subsection{Construction (CONSTR)}

In the construction activity, the behaviour of the variable ln_GDP is different from country to country. For example, for Spain we expect stationary series but as regards the other three countries a slow trend may be possible. The presence of breaks is evident. Related to the UR variables the trend change after the breaks is visible but the behaviour is relatively similar in all the countries. The unit root tests based on panel data have had ambiguous results when the model included only intercept component and then trend + intercept (Appendix). The time series analysis suggested that all the variables could be assumed as I(1). In this case we have studied the existence of cointegration relations between variables.

When performed the Pedroni, Kao and Johansen-Fisher combined tests, they suggested that variables are not cointegrated. However, a cointegration relationship was found between EMI and KSI variables. This information helped us to correctly specify the $\operatorname{ARDL}(\mathrm{p}, \mathrm{d}, \mathrm{q})$ model as we mentioned before. We have decided to use this method again due to the fact that certain series such as GVA/lnGVA might not be quite I(1) but nearly $\mathrm{I}(1)$, recalling that in this case we may introduce in the relation combination of $\mathrm{I}(0)$ and I(1) variables.

We have presented the results of the estimated equations in Table 5.

Table 5. Long run and short run relation between GVA and UR in Construction (CONSTR)

\begin{tabular}{|c|c|c|c|}
\hline Variables & $\operatorname{ARDL}(1,1)$ & $\begin{array}{l}\text { ARDL }(1,1,1) \\
\text { EMI included }\end{array}$ & $\begin{array}{l}\text { ARDL }(1,1,1) \\
\text { KSI included }\end{array}$ \\
\hline \multicolumn{4}{|c|}{ Dependent variable $\Delta U R$} \\
\hline \multicolumn{4}{|l|}{ Long run } \\
\hline $\operatorname{lnGVA}$ & $-10.42^{\star \star}$ & $-10.971^{\star \star}$ & -6.23 \\
\hline EMI & & 0.439 & \\
\hline KSI & & & $-90.44^{\star * *}$ \\
\hline \multicolumn{4}{|l|}{ Short run eq } \\
\hline Cointeq term $(\alpha)$ & $-0.289^{* * *}$ & $-0.27^{\star *}$ & $-0.349^{\star * *}$ \\
\hline$\Delta \ln \_$GVA & $-42.13^{* * *}$ & $-41.31^{* * *}$ & $35.99^{* * *}$ \\
\hline EMI & & 0.403 & \\
\hline$\Delta \mathrm{KSI}$ & & & $17.71^{\star}$ \\
\hline Dummy & $1.406^{\star *}$ & $1.162^{\star}$ & 1.11 \\
\hline $\mathrm{C}$ & $36.78^{\star *}$ & $36.59^{*}$ & $40.56^{* * *}$ \\
\hline
\end{tabular}


We estimated here three types of ARDL models, introducing along with ln_GVA one exogenous variable more, first EMI and then KSI. When the analysis was made only between UR and ln_GVA we found a significant relationship. The same relation between unemployment and GVA remains significant when EMI is included. Each time the cointegration term was found significant.

Moreover the sectoral specialization, measured through KSI seems to play a significant role in explaining UR dynamics as ARDL $(1,1,1)$ results, from Table 5, underline.

\subsection{Mining and quarrying; Electricity, gas and water supply (MIN)}

As in Construction activity, in Mining and quarrying; Electricity, gas and water supply (MIN) sector, all the variables have oscillating evolutions and changing trends, especially in the period near the crisis. These observations have been supported by the results from structural break analysis and unit root examination.

Panel unit root analysis (Appendix) confirms the above mentioned hypotheses i.e. that all the variables included in the analysis could be considered I(1). In this case Panel Cointegration tests of Pedroni (2004), Kao (1999) and Johansen (2002) have been applied. The last two tests suggest the existence of one cointegration relation. In this regard, an ECM model has been estimated.

Table 6. Panel Data Analysis results for Mining and quarrying; Electricity, gas and water supply (MIN)

\begin{tabular}{|c|c|c|c|}
\hline Variables & $\begin{array}{c}\text { ECM } \\
\text { KSI and EMI included } \\
(1)\end{array}$ & Variables & $\begin{array}{c}\text { ECM with KSI and } \\
\text { EMI included as exog- } \\
\text { enous (2) }\end{array}$ \\
\hline \multicolumn{4}{|l|}{ Long run } \\
\hline $\mathrm{UR}(-1)$ & 1 & $\mathrm{UR}(-1)$ & 1 \\
\hline $\ln \_G V A(-1)$ & $-26.05^{\star *}$ & ln_GVA(-1) & $16.96^{* *}$ \\
\hline $\mathrm{KSI}(-1)$ & -3.920 & $\mathrm{KSI}(-1)$ & \\
\hline $\operatorname{EMI}(-1)$ & $13.42^{\star *}$ & $\operatorname{EMI}(-1)$ & \\
\hline trend & $0.649^{* *}$ & trend & 0.24 \\
\hline c & 137.5 & $c$ & \\
\hline \multicolumn{4}{|c|}{ ECM with $\Delta \mathrm{UR}$ as dependent variable } \\
\hline Cointeq term $(\alpha)$ & $-0.077^{* *}$ & Cointeq term & $-0.105^{\star *}$ \\
\hline$\Delta\left(\ln \_\right.$GVA $\left.(-1)\right)$ & -2.662 & $\Delta\left(\ln \_G V A(-1)\right)$ & -7.529 \\
\hline$\Delta \mathrm{UR}(-1)$ & -0.027 & $\Delta \mathrm{UR}(-1)$ & 0.149 \\
\hline$\Delta(\operatorname{EMI}(-1)$ & $2.718^{\star *}$ & $\Delta(\operatorname{EMI}(-1)$ & $2.931^{*}$ \\
\hline$\Delta(\mathrm{KSI}(-1)$ & $46.69^{* *}$ & $\Delta(\mathrm{KSI}(-1)$ & \\
\hline Dummy & $2.21^{* *}$ & Dummy & 0.408 \\
\hline $\mathrm{C}$ & $-0.684^{*}$ & $\mathrm{C}$ & $-3.359^{*}$ \\
\hline $\mathrm{R}^{2}$ & 0.246 & $\mathrm{R}^{2}$ & 0.118 \\
\hline
\end{tabular}


We have found a long-run relationship between UR and ln_GVA in the MIN sector as in the other secondary sectors. ECM model predict moreover an impact of GVA growth on unemployment dynamics than vice versa. The ARDL model suggests an impact of EMI on unemployment rate on the short term (Table 6).
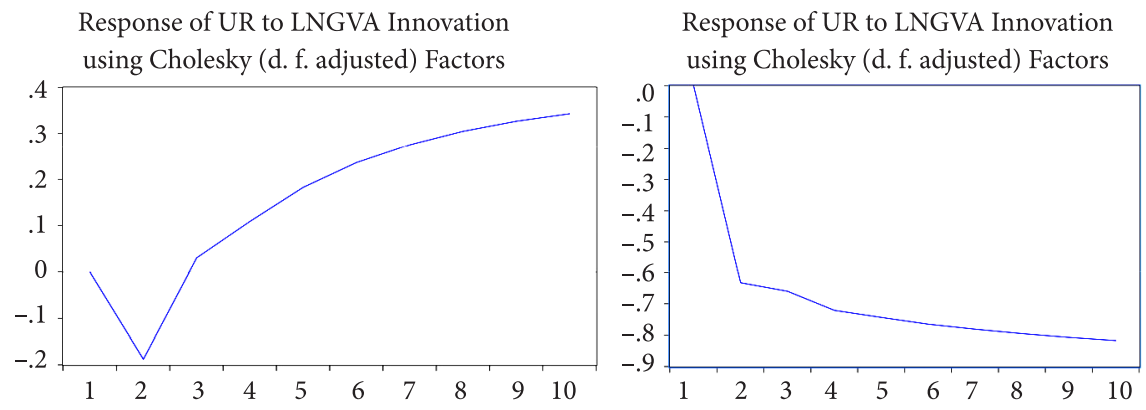

Figure 2. The impulse-response function when KSI and EMI are endogenous (left) and when KSI and EMI are exogenous (right)

If educational mismatches and specialization are considered results of the system (i.e endogenous), the shock of the GVA will have a short positive impact, decreasing UR, but on a long term the shock will produce also the unemployment increase (Figure 2). This result should be put in the context of emerging new resources, renewable, which may determine an unemployment increase if a shift of resources utilization appears.

Assuming specialization and educational mismatch as exogenous variables, when impulse-response function is analysed, it seems that a positive shock given to GVA from MIN sector will cause a sudden decrease of UR in the first years. The shock persist on long term showing thus a positive effect of the economic development on the unemployment sector.

\subsection{Trade, transportation, accommodation and food, and business and administrative services (TRADE)}

In this sector (TRADE), GVA growth and UR have significant fluctuations. Both indicators' behaviour suggests the presence of structural breaks. These hypotheses have been back up by the CUSUM of Squares and unit root test applied on each of the time series.

Based on these tests we concluded that all variables are $\mathrm{I}(0)$ or $\mathrm{I}(1)$, but none of them is I(2) (Appendix). As a result we estimated an ARDL model in order to analyse both short term and long-term relations. The results are provided in the Table 7.

As regards Trade sector we have found a statistically significant long-run relationship between GVA change and unemployment rate, only when educational mismatch index (EMI) was included in the model. The negative coefficient of GVA in both short run and long run equations confirms the hypothesis from economic theory. The KSI has also significant impact, but seems rather to disturb the relation between main economic variables on the long run. 
Table 7. Panel unit root results for Trade, transportation, accommodation and food, and business and administrative services (TRADE)

\begin{tabular}{|c|c|c|}
\hline Variables & $\begin{array}{c}\text { Model } 1 \text { (ARDL }(1,1,1) \\
\text { KSI included }\end{array}$ & $\begin{array}{c}\text { Model } 2(\operatorname{ARDL}(1,1,1) \\
\text { EMI included }\end{array}$ \\
\hline \multicolumn{3}{|c|}{ Dependent variable $\Delta U R$} \\
\hline \multicolumn{3}{|l|}{ Long run } \\
\hline Ln_GVA & 0.88 & $-9.61^{* * *}$ \\
\hline KSI & $-66.67^{\star *}$ & \\
\hline EMI & & $3.21^{\star * *}$ \\
\hline \multicolumn{3}{|l|}{ Short run eq } \\
\hline Cointeq term & $-0.25^{\star * *}$ & $-0.21^{\star * *}$ \\
\hline $\mathrm{D}\left(\ln \_\mathrm{GVA}\right)$ & $-41.5^{\star \star \star}$ & $-35.03^{\star * *}$ \\
\hline $\mathrm{D}(\mathrm{KSI})$ & 3.03 & \\
\hline $\mathrm{D}(\mathrm{EMI})$ & & 0.84 \\
\hline Dummy & $0.68^{*}$ & 0.37 \\
\hline $\mathrm{C}$ & 8.19 & $23.94^{* * *}$ \\
\hline
\end{tabular}

Note: coefficient is significant at level: ${ }^{* \star}$ lower than $1 \%$; ${ }^{\star \star} 1-5 \% ;{ }^{\star} 6-10 \%$.

\subsection{Public administration, community, social and other services and activities-ADM)}

In Public Administration, GVA and unemployment rate dynamics show almost similar patterns in the four Mediterranean countries in our sample: slow trends in ln_GVA and visible oscillations in UR.

When we have combined the results of the time series analysis (structural break and unit root tests) with panel data analysis (panel unit root tests) we have decided that we have a mix of $\mathrm{I}(0)$ and $\mathrm{I}(1)$ variables and that ARDL modelling is the best estimation method (Appendix).

Table 8. Panel analysis results for in Public Administration, Community, Social and other Services and Activities (ADM)

\begin{tabular}{|c|c|c|c|}
\hline Variables & Model 1 (ARDL $(1,1)$ & $\begin{array}{l}\text { Model } 2(\operatorname{ARDL}(1,1,1) \\
\text { EMI included }\end{array}$ & $\begin{array}{c}\text { Model } 3 \text { (ARDL }(1,1,1) \\
\text { KSI included }\end{array}$ \\
\hline \multicolumn{4}{|c|}{ Dependent variable $\Delta U R$} \\
\hline \multicolumn{4}{|l|}{ Long run } \\
\hline Ln_GVA & -5.359 & $-2.912^{\star \star}$ & -4.327 \\
\hline KSI & & & $-49.35^{\star \star}$ \\
\hline EMI & & $-3.006^{* * *}$ & \\
\hline \multicolumn{4}{|l|}{ Short run eq } \\
\hline Cointeq term & $-0.347^{\star * *}$ & $-0.270^{* * *}$ & $-0.380^{* * *}$ \\
\hline $\mathrm{D}\left(\mathrm{ln} \_\mathrm{GVA}\right)$ & $-44.35^{\star * *}$ & $-33.22^{\star *}$ & $-33.31^{\star * *}$ \\
\hline $\mathrm{D}(\mathrm{KSI})$ & & & -7.137 \\
\hline $\mathrm{D}(\mathrm{EMI})$ & & $1.343^{\star * *}$ & \\
\hline Dummy (DUM) & $1.455^{\star \star \star}$ & $1.686^{\star *}$ & $1.735^{\star \star}$ \\
\hline $\mathrm{C}$ & $24.09^{\star * \star}$ & 15.741 & $30.414^{* * *}$ \\
\hline
\end{tabular}


A relation between GVA change and unemployment rate in public sector was not found significant from statistical point of view in long run relation excepting when EMI indicator was included (Table 8). Rather, it seems that an increase of GVA has a positive impact, reduction of unemployment only on short run. Educational mismatch index plays an important role in explaining unemployment dynamic.

\section{Conclusions}

The recent period has been characterized in all the analyzed countries by low economic growth rates, very high unemployment rates, polarization of wealth and increasing the number of people below the poverty line.

The literature review part has focused on studies that looked at the relationship economic growth-unemployment rate, describing the manner in which Okun's Law model has been applied and improved in order to capture the particularities of different countries. Thereby, the results of these studies pointed to some features of application of the above mentioned law: a regionally dualism in Spain caused mainly by differences in productivity and the need for targeted solutions for those two categories of regions; exacerbation, in times of crisis, of unemployment response to fluctuations in economic growth, in Greece, and the need to combine measures to stimulate aggregate demand with structural ones; structural rather than cyclical character of unemployment rate in Italy, proving problems related to the poor reallocation of human resources between sectors and between regions; structural weaknesses of Portuguese economy which made it difficult adapting to recession conditions.

Empirical analysis has focused on two objectives: to statistically describe the general economic context in which the labour markets are functioning and to capture the particularities of the relationship economic growth - unemployment rate at sectoral level.

The analysis of the GVA structure by sector in the past two decades in the four Mediterranean countries emphasizes the similarities between them, namely: the contribution relatively low of the agriculture and industry to output creation, dependency rather high on the construction sector, high share of market and non-market services in total output. The last twenty years developments, accelerated in the aftermath of the crisis, point to a trend of deindustrialization and the decline of the construction sector, increasing the share of trade sector in GVA structure. All these economic features of the four countries are also reflected by the structure of unemployment: large shares of the unemployed coming from the service sector and an exacerbation of unemployment in construction activity.

Statistical indexes (Krugman specialisation index and educational mismatch index) were computed for all countries based on sectoral indicators, with the aim to capture different aspects of economic transformations that have an impact on labour market dynamics, more precisely on unemployment. From this point of view, countries in our sample have many common features, but also some specificity: Portugal and Spain seem to be countries with higher degree of specialization than others, in Italy educational mismatches are the highest.

Including these indexes as explanatory variables along with the economic growth rates in the econometric modelling allowed capturing the particularities of the causal relations established at sector of activity level. 
As regards agriculture, it is worth noting that unemployment rate is less sensitive to output fluctuations. Rather it can become a buffer in times of economic depression for unemployed and more than that for low educated unemployed.

Conversely, in manufacturing, unemployment rate is highly responsive to output dynamics and seems to be significantly influenced by the degree of specialization. Moreover the relationship between those two variables (unemployment and degree of specialisation) could be a sign of the existence of bad specialization and labour market mismatches. The same situation is noticeable in the Mining and quarrying; Electricity, gas and water supply sector.

Construction is the activity in which the relationship unemployment rate - GVA growth proved to be very strong and the influence was manifested in both directions: from unemployment rate to GVA growth and vice versa.

Trade, Transportation, Accommodation and Food, Business and Administrative Services activities are characterized by a long-term negative relationship between unemployment rate and GVA growth. One factor that contributes to a better explanation of this relationship is EMI. It captures the impact of mismatches on the efficient function of the labour market.

The disequilibrium rates from the long run relationships in all fields are lying in the $30-40 \%$ showing that a shock from the long-run relation will be absorbed in 3-4 years.

A significant impact of output fluctuations on unemployment dynamics can be highlighted in the Public Administration, Community, Social and other Services and Activities sector in particular for mismatched workers. In these Mediterranean countries, and others affected by the crisis, overcoming the moment of decline involved also many problems for the workers in the public system.

In terms of the impact of specialization on unemployment, we have demonstrated that specialization and moreover bad specialization could explain the existence of those high unemployment rates in industrial sectors. Educational mismatches, instead, seem to influence unemployment, especially in industries that employ low educated people.

Thus, in a nutshell, we can conclude that: industry, as a whole, is highly responsive to output fluctuations in terms of unemployment and solutions to this important problem could be workers/unemployed reallocations between sectors, moreover towards highly productive sectors (good specialization); agriculture can become the sector that supports economic growth and even jobs creation in difficult times; educational mismatches have a significant negative impact on unemployment in those sectors of activity that employed low educated workforce.

We have found many similarities between these four Mediterranean countries in terms of the long and short-term relationship between unemployment rate and potential factors of influence. These findings confirm the idea of treating them as a group. Although, for the moment our analysis could not cover a larger group of EU countries for the reasons outlined above, our goal is to analyze in the future other groups of countries (e.g. Visegrad group or other newly entry countries in EU) and finally to extend the analysis to all $28 / 27$ EU members. 


\section{References}

Apergis, N., \& Rezitis, A. (2003). An examination of Okun's law: evidence from regional areas in Greece. Applied Economics, 35(10), 1147-1151. https://doi.org/10.1080/0003684032000066787

Azorin, J. D. B., \& De la Vega, M. D. S. (2017). Output growth thresholds for the creation of employment and the reduction of unemployment: a spatial analysis with panel data from the Spanish provinces, 2000-2011. Regional Science and Urban Economics, 67(C), 42-49. https://doi.org/10.1016/j.regsciurbeco.2017.08.004

Bolat, S., Tiwari, A. K., \& Erdayi, A. U. (2014). Unemployment hysteresis in the Eurozone area: evidences from nonlinear heterogeneous panel unit root test. Applied Economics Letters, 21, 536-540. https://doi.org/10.1080/13504851.2013.872755

Busetta, G., \& Corso, D. (2012). Labor productivity and Okun's law: an empirical application to Italian region panel date. Rivista Italiana degli Economisti, 2(2), 279-298.

Camarero, M., Carrion-i-Silvestre, J. L., \& Tamarit, C. (2006). Testing for hysteresis in unemployment in OECD countries: new evidence using stationarity panel tests with breaks. Oxford Bulletin of Economics and Statistics, 68(2), 167-182. https://doi.org/10.1111/j.1468-0084.2006.00157.x

Canon, M. E., Chen, M., \& Marifian, E. A. (2013). Labour mismatch in the great recession: a review of indexes using recent U.S. data. Federal Reserve Bank of St. Louis Review, 95(3), 237-271.

Carrion-i-Silvestre, J. L., del Barrio, T., \& López, E. (2002). Breaking the panels. An application to the GDP per capita, AQR Research Group. Department of Econometrics, Statistics and Spanish Economy. University of Barcelona. Retrieved from http://citeseerx.ist.psu.edu/viewdoc/download? doi=10.1.1.202.2085\&rep=rep1\&type $=$ pdf

Cheng, S. C., Wu, T., \& Chang, T. (2014). Flexible Fourier unit root test of unemployment for PIIGS countries. Economic Modelling, 36, 142-148. https://doi.org/10.1016/j.econmod.2013.09.021

Choi, I. (2015). Almost all about unit roots foundations, developments and applications. Cambridge University Press. https://doi.org/10.1017/CBO9781316157824

Christopoulos, D. K. (2004). The relationship between output and unemployment: evidence from Greek regions. Papers in Regional Science, 83(3), 611-620.

https://doi.org/10.1111/j.1435-5597.2004.tb01928.x

COMM. (2013). Labour market developments in Europe 2013, European Economy 6/2013. European Commission, Brussels, Belgium.

Dritsaki, C., \& Dritsakis, N. (2009). Okun's coefficient for Four Mediterranean Member Countries of EU: An Empirical Study. International Journal of Business and Management, 4(5), 18-26. https://doi.org/10.5539/ijbm.v4n5p18

Di Pietro, G., \& Urwin, P. (2006). Education and skills mismatch in the Italian graduate labour market. Applied Economics, 38(1), 79-93. https://doi.org/10.1080/00036840500215303

Dickey, P. A., \& Fuller, W. A. (1979). Distribution of the estimators for autoregressive time-series with a unit root. Journal of the American Statistical Association, 74(366), 427-431. https://doi.org/10.2307/2286348

Dinu, M., Marinas, M. C., Socol, C., \& Socol, A. G. (2011). Testing the Okun's law in Romania. Economic Computation and Economic Cybernetics Studies and Research, 1, 5-21.

Eichhorst, W., \& Neder, F. (2014). Youth unemployment in Mediterranean Countries. IZA Policy Paper No 80. Retrieved from http://ftp.iza.org/pp80.pdf

Eliott, G., Rothenberg, T., \& Stock, J. (1996). Efficient tests for an autoregressive unit root. Econometrica, 64(4), 813-836. https://doi.org/10.2307/2171846

Enders, W., \& Lee, J. (2012). The flexible Fourier form and the Dickey-Fuller type unit root tests. Econ Letters, 117(1), 196-199. https://doi.org/10.1016/j.econlet.2012.04.081 
European Central Bank (ECB). (2004). Sectoral specialization in the EU. A Macroeconomic Perspective, Occasional Paper Series, No.19/July 2004. Retrieved from https://www.ecb.europa.eu/pub/pdf/ scpops/ecbocp19.pdf

Eurostat. (2018). Official statistics of European Union. Retrieved from http://ec.europa.eu/eurostat/data/ database

Ezcurra, R. (2011). Unempoyment volatility and regional specialization in the European Union. Regional Studies, 45(8), 1121-1137. https://doi.org/10.1080/00343401003713332

Furceri, D., \& Mourougane, A. (2012). How do institutions affect structural unemployment in times of crises? Panoeconomicus, 4, 393-419. https://doi.org/10.2298/PAN1204393F

Furuoka, F. (2014). Are unemployment rates stationary in Asia-Pacific countries? New findings from Fourier ADF test. Economic Research, 27, 34-45. https://doi.org/10.1080/1331677X.2014.947105

Furuoka, F. (2017). A new approach to testing unemployment hysteresis. Empirical Economics, 53, 1253-1280. https://doi.org/10.1007/s00181-016-1164-7

Gabrisch, H., \& Bruscher, H. (2006). The relationship between unemployment and output in Postcommunist countries. Post-Communist Economies, 18(3), 261-276. https://doi.org/10.1080/14631370600881804

Garcia-Cintado, A., Romero-Avila, D., \& Usabiaga, C. (2015). Can the hysteresis hypothesis in Spanish regional unemployment be beaten? New evidence from unit root tests with breaks. Economic Modelling, 47, 244-252. https://doi.org/10.1016/j.econmod.2015.02.035

Garibaldi, P., \& Taddei, F. (2013). Italy: A dual labour market in transition, ILO, Employment Sector. Employment Working Paper No. 144.

Garonna, P., \& Sica, F. G. M. (2000). Intersectoral labour reallocations and unemployment in Italy. Labour Economics, 7(6), 711-728. https://doi.org/10.1016/S0927-5371(00)00018-X

Ghita, S.I., Saseanu, A.S., Gogonea, R.M., \& Huidumac-Petrescu, C.E. (2018). Perspectives of ecological footprint in European context under the impact of information society and sustainable development. Sustainability, 10(9), 3224.

Hadri, K. (2000). Testing for unit roots in heterogeneous panel data. Econometrics Journal, 3, 148-161.

Hall, C. (2016). Does more general education reduce the risk of future unemployment? Evidence from an expansion of vocational upper secondary education. Economics of Education Review, 52, 251271. https://doi.org/10.1016/j.econedurev.2016.03.005

Harvey, D. I., Leybourne, S. J., \& Taylor, A. M. R. (2013). Testing for unit roots in the possible presence of multiple trend breaks using minimum Dickey-Fuller statistics. Journal of Econometrics, 177, 265284. https://doi.org/10.1016/j.jeconom.2013.04.012

Holden, S., \& Sparrman, V. (2017). Do government purchases affect unemployment?. Scandinavian Journal of Economics, 120(1), 124-158. https://doi.org/10.1111/sjoe.12214

Hooper, V. (2017). Okun's law revisited within the context of high eurozone unemployment: a note. E-Journal of International and Comparative Labour Studies, 6(2), 156-159.

Huang, H. C., \& Yeh, C. C. (2013). Okun's law in panels of countries and states. Applied Economics, 45(2), 191-199. https://doi.org/10.1080/00036846.2011.597725

ILO. (2014a). Greece: productive jobs for Greece. International Labour Organization, Research Department, Geneva.

ILO. (2014b). Spain. Growth with jobs. International Labour Organization, Research Department, Geneva.

ILO. (2014c). Portugal. Tackling the jobs crisis in Portugal. International Labour Organization, Research Department, Geneva. 
Im, K. S., \& Lee, J. (2001). Panel LM unit root tests with level shifts. Department of Economics, University of Central Florida, Orlando. Retrieved from https://pdfs.semanticscholar.org/794e/035e2af830 b66f5d229cd444cbc8b34c3d83.pdf

Im, K. S., Pesaran, M. H., \& Shin, Y. (2003). Testing for unit roots in heterogeneous panels. Journal of Econometrics, 115, 53-74. https://doi.org/10.1016/S0304-4076(03)00092-7

Im, K. S., Pesaran, M. H., \& Shin, Y. (1997). Testing for unit roots in heterogeneous panels. Department of Applied Economics, University of Cambridge.

Johansen, K. (2002). Hysteresis in unemployment: evidence from Norwegian counties. Working Paper series No.6/2002, Department of Economics, Norwegian University of Science and Technology.

Kao, C. D. (1999). Spurious regression and residual-based tests for cointegration in panel data. Journal of Econometrics, 90, 1-44. https://doi.org/10.1016/S0304-4076(98)00023-2

Karfakis, C., Katrakilidis, K., \& Tsanana, E. (2014). Does output predict unemployment? A look at Okun's law in Greece. International Labour Review, 153, 421-433. https://doi.org/10.1111/j.1564-913X.2014.00018.x

Khraief, N., Shahbaz, M., Heshmati, A., \& Azam, M. (2015). Are unemployment rates in OECD countries stationary? Evidence from univariate and panel unit root tests. Discussion Paper 9571. Retrieved from http://ftp.iza.org/dp9571.pdf

Li, J. P., Ranjbar, O., \& Chang, T. (2017). Unemployment hysteresis in PIIGS countries: a ney test with both sharp and smooth breaks. The Singapore Economic Review, 62(05), 1165-1177. https://doi.org/10.1142/S0217590815500782

Maddala, G. S., \& Wu, S. (1999). A comparative study of unit root tests with panel data and a new simple test. Oxford Bulletin of Economics and Statistics, 61, 631-652.

https://doi.org/10.1111/1468-0084.61.s1.13

Maria, J. R. (2016). Output and unemployment Portugal, 2008-2012. Working Papers 2016, Banco de Portugal, Lisbon. Retrieved from https://www.bportugal.pt/sites/default/files/anexos/papers/ wp201603.pdf

Matuzeviciute, K., Butkus, M., \& Karaliute, A. (2017). Do technological innovations affect unemployment? Some empirical evidence from European countries. Economies, 5(4), article number 48. https://doi.org/10.3390/economies5040048

Mitra, D., \& Ranjan, P. (2010). Offshoring and unemployment: the role of search frictions labor mobility. Journal of International Economics, 81(2), 219-229. https://doi.org/10.1016/j.jinteco.2010.04.001

Mongelli, F. P., Dorrucci, E., Ioannou, D., \& Terzi, A. (2015). Responses to the Euro area crisis: measuring the path of European Institutional Integration. Journal of European Integration, 37(7), 769-786. https://doi.org/10.1080/07036337.2015.1079373

Narayan, P. K., \& Popp, S. (2010). A new unit root test with two structural breaks in level and slope at unknown time. Journal of Applied Statistics, 37, 1425-1438. https://doi.org/10.1080/02664760903039883

OECD Statistics. (2018). Retrieved from https://stats.oecd.org/

Ortego-Marti, V. (2017). Difference in skill loss during unemployment across industries and occupations. Economics Letters, 161, 31-33. https://doi.org/10.1016/j.econlet.2017.09.006

Paciello, M. C. (2010). The impact of the economic crisis on Euro-Mediterranean relations. The International Spectator, Italian Journal of International Affairs, 45(3), 51-69. https://doi.org/10.1080/03932729.2010.504622

Patrizia, O., \& Giuseppe, R. (2015). Educational mismatch and unemployment scarring. International Journal of Manpower, 36(5), 733-753. https://doi.org/10.1108/IJM-03-2013-0048

Pedroni, P. (2004). Panel cointegration; asymptotic and finite sample properties of pooled time series tests with an application to the PPP hypothesis. Econometric Theory, 20, 597-625.

https://doi.org/10.1017/S0266466604203073 
Perron, P., \& Vogelsang, T. J. (1992). Nonsationarity and level shifts with an application to purchasing power parity. Journal of Business and Economic Statistics, 10, 301-320.

Perman, R., Gaetan, S., \& Tavera, C. (2013). Okun's law - a meta analysis. SIRE Discussion Paper 201359. Scottish Institute for Research in Economics. Retrieved from http://repo.sire.ac.uk/bitstream/ handle/10943/486/SIRE-DP-2013-59.pdf?sequence=1\&isAllowed $=y$

Pesaran, M. H., \& Shin, Y. (1999). An autoregressive distributed lag modeling approach to cointegration analysis. In S. Strom, A. Holly, \& P. Diamond (Eds.). Centennial Volume of Rangar Frisch, Cambridge University Press, Cambridge. Retrieved from http://citeseerx.ist.psu.edu/viewdoc/downloa $\mathrm{d}$ ? doi=10.1.1.153.3246\&rep=rep1\&type $=$ pdf

Phelps, E. S. (1998). Structural slumps - the modern theory of unemployment, interest and assets. Cambridge, MA: Harvard University Press.

Rios, V. (2016). What drives unemployment disparities in European regions? A dynamic spatial panel approach. Regional Studies, 11, 1-13.

Tatoglu, Y. F. (2011). The long and short run effects between unemployment and economic growth in Europe. Doğuş University Journal, 12(1), 99-113.

Turner, P. (2010). Power properties of the CUSUM and CUSUMSQ tests for parameter instability. Applied Economics Letters, 17(11), 1049-1053. https://doi.org/10.1080/00036840902817474.

Suciu, M. C., \& Florea, C. A. (2017). An empirical study on the migration among young skilled and creative people. Amfiteatrul Economic, 19(46), 727-741.

Syssoyeva-Masson, I., \& Andrade, J. (2017). Are PIIGS so Different? An empirical analysis of demand and supply shocks. Panoeconomicus, Special Issue, 64(2), 189-222. https://doi.org/10.2298/PAN1702189S

Van Ours, J. C. (2015). The Great Recession was not so great. Labour Economics, 34(C), 1-12. https://doi.org/10.1016/j.labeco.2015.02.001

Villaverde, J., \& Maza, A. (2007). Okun's law in the Spanish regions. Economics Bulletin, 18(5), 1-11.

Villaverde, J., \& Maza, A. (2009). The robustness of Okun's law in Spain, 1980-2004: regional evidence. Journal of Policy Modelling, 31(2), 289-297. https://doi.org/10.1016/j.jpolmod.2008.09.003

Vogelsang, T., \& Perron, P. (1998). Additional tests for a unit root allowing for a break in the trend function at an unknown time. International Economic Review, 39(4), 1073-1100. https://doi.org/10.2307/2527353

Zanin, L. (2018). The pyramid of Okun's coefficient for Italy. Empirica, 45(1), 17-28. https://doi.org/10.1007/s10663-016-9343-5

Zhang, J. (2017). Unemployment benefits and matching efficiency in an estimated DSGE model with labor market search frictions. Macroeconomics Dynamics, 21(8), 2033-2069.

https://doi.org/10.1017/S1365100516000109 


\section{APPENDIX}

Unit root results for 6 economic sector (AGR, MAN, CONSTR, MIN, TRADE, ADM) and 4 countries (Greece, Italy, Portugal and Spain), 1995-2017

Unit root results for AGR

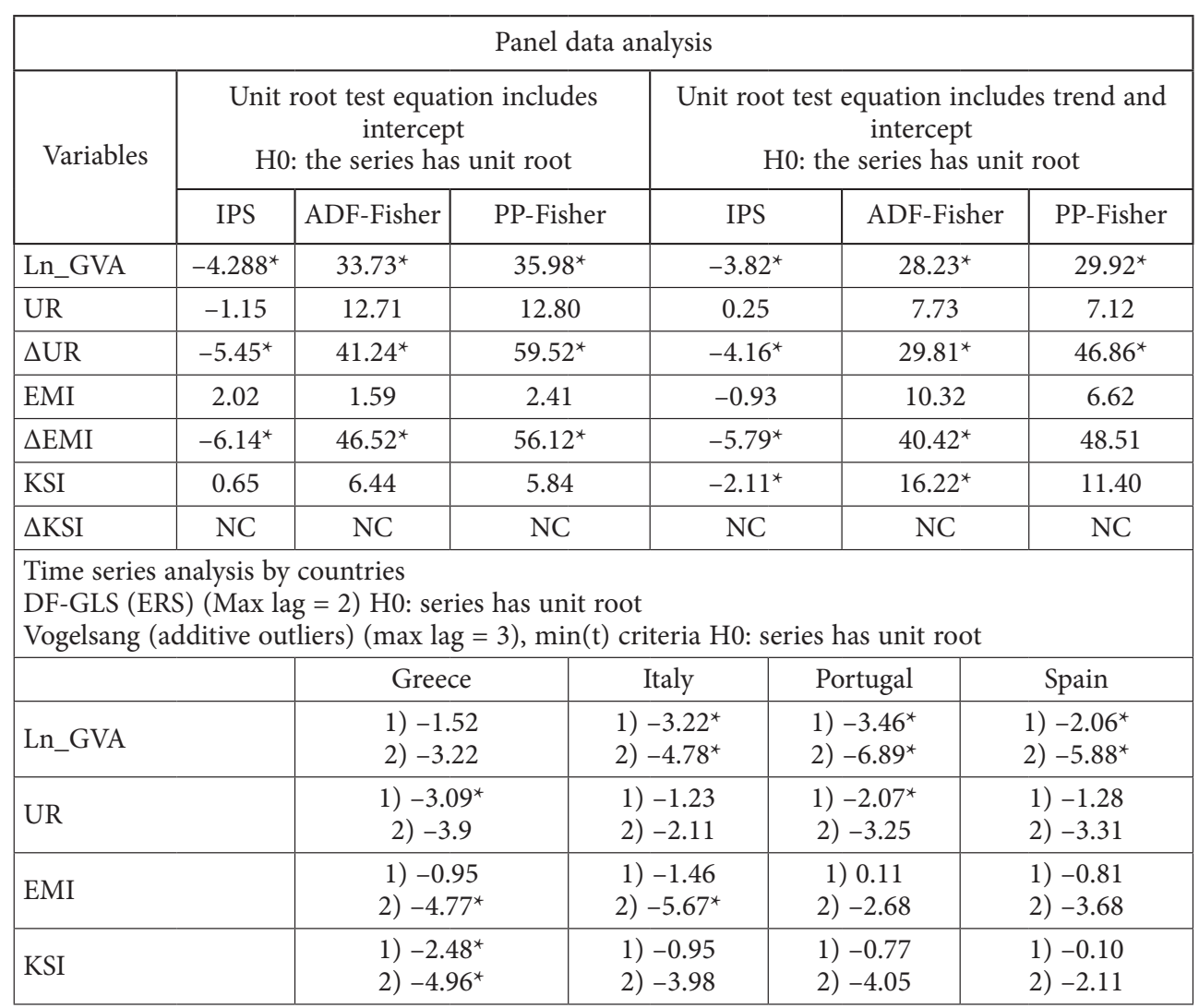

${ }^{*}$ reject null hypothesis at 0.05 level., N/A not available or not performed, N/C not the case.

Unit root results for MAN

Panel data analysis

\begin{tabular}{|l|c|c|c|c|c|c|}
\hline \multicolumn{7}{|c|}{ Panel data analysis } \\
\hline Variables & \multicolumn{2}{|c|}{$\begin{array}{c}\text { Unit root test equation includes intercept } \\
\text { H0: the series has unit root }\end{array}$} & $\begin{array}{r}\text { Unit root test equation includes trend and } \\
\text { intercept } \\
\text { H0: the series has unit root }\end{array}$ \\
\hline & IPS & ADF-Fisher & PP-Fisher & IPS & ADF-Fisher & PP-Fisher \\
\hline Ln_GVA & $-3.63^{*}$ & $27.64^{*}$ & $19.47^{*}$ & $-2.42^{*}$ & $18.57^{*}$ & 10.91 \\
\hline$\Delta$ Ln_GVA & N/A & N/A & N/A & N/A & N/A & N/A \\
\hline UR & -0.05 & 5.82 & 5.01 & -0.99 & 10.19 & 5.88 \\
\hline
\end{tabular}




\begin{tabular}{|c|c|c|c|c|c|c|}
\hline \multicolumn{7}{|c|}{ Panel data analysis } \\
\hline \multirow[t]{2}{*}{ Variables } & \multicolumn{3}{|c|}{$\begin{array}{l}\text { Unit root test equation includes intercept } \\
\text { H0: the series has unit root }\end{array}$} & \multicolumn{3}{|c|}{$\begin{array}{l}\text { Unit root test equation includes trend and } \\
\text { intercept } \\
\text { H0: the series has unit root }\end{array}$} \\
\hline & IPS & ADF-Fisher & PP-Fisher & IPS & ADF-Fisher & PP-Fisher \\
\hline$\Delta \mathrm{UR}$ & $-5.09^{\star}$ & $38.71^{*}$ & $42.82^{*}$ & $\mathrm{NC}$ & $\mathrm{NC}$ & NC \\
\hline \multicolumn{7}{|c|}{$\begin{array}{l}\text { Time series analysis by countries } \\
\text { DF-GLS (ERS) (Max lag = 2) H0: series has unit root } \\
\text { 2) Vogelsang (additive outliers) }(\max \operatorname{lag}=3), \min (\mathrm{t}) \text { criteria H0: series has unit root }\end{array}$} \\
\hline & & Greece & Italy & Portugal & \multicolumn{2}{|c|}{ Spain } \\
\hline \multicolumn{2}{|l|}{ Ln_GVA } & $\begin{array}{l}\text { 1) }-2.98^{\star} \\
\text { 2) }-6.56^{*}\end{array}$ & $\begin{array}{l}\text { 1) }-2.57^{\star} \\
\text { 2) }-4.03\end{array}$ & $\begin{array}{l}\text { 1) }-2.02^{*} \\
\text { 2) }-4.58^{*}\end{array}$ & \multicolumn{2}{|c|}{$\begin{array}{l}\text { 1) }-1.55 \\
\text { 2) }-2.65\end{array}$} \\
\hline \multicolumn{2}{|l|}{ UR } & $\begin{array}{l}\text { 1) }-2.32^{*} \\
\text { 2) }-4.25\end{array}$ & $\begin{array}{l}\text { 1) }-1.83 \\
\text { 2) } 3.96\end{array}$ & $\begin{array}{l}\text { 1) }-1.28 \\
\text { 2) }-3.59\end{array}$ & \multicolumn{2}{|c|}{$\begin{array}{l}\text { 1) }-1.35 \\
\text { 2) }-3.46\end{array}$} \\
\hline
\end{tabular}

${ }^{\star}$ reject null hypothesis at 0.05 level., N/A not available or not performed, N/C not the case.

Unit root results for CONSTR

\begin{tabular}{|c|c|c|c|c|c|c|}
\hline \multicolumn{7}{|c|}{ Panel data Analysis } \\
\hline \multirow[t]{2}{*}{ Variables } & \multicolumn{3}{|c|}{$\begin{array}{c}\text { Unit root test equation includes inter- } \\
\text { cept } \\
\text { H0: the series has unit root }\end{array}$} & \multicolumn{3}{|c|}{$\begin{array}{l}\text { Unit root test equation includes trend } \\
\text { and intercept } \\
\text { H0: the series has unit root }\end{array}$} \\
\hline & IPS & ADF-Fisher & PP-Fisher & IPS & ADF-Fisher & PP-Fisher \\
\hline Ln_GVA & -1.54 & -14.80 & 1.49 & -0.63 & 10.02 & 2.70 \\
\hline$\Delta$ Ln_GVA & $-1.90^{*}$ & $18.17^{\star}$ & $18.53^{*}$ & -1.44 & $15.79^{\star}$ & 13.63 \\
\hline UR & -0.05 & 7.02 & 1.3 & 0.30 & 5.84 & 2.89 \\
\hline$\Delta \mathrm{UR}$ & $-2.77^{\star}$ & $21.21^{\star}$ & $21.11^{*}$ & $\mathrm{NC}$ & NC & $\mathrm{NC}$ \\
\hline \multicolumn{7}{|c|}{$\begin{array}{l}\text { Time series analysis by countries } \\
\text { DF-GLS (ERS) (Max lag }=2) \text { H0: series has unit root } \\
\text { Vogelsang (additive outliers) }(\max l a g=3), \min (\mathrm{t}) \text { criteria H0: series has unit root }\end{array}$} \\
\hline & & Greece & Ita & & Portugal & Spain \\
\hline Ln_GVA & & $\begin{array}{l}\text { 1) }-0.89 \\
\text { 2) }-3.51\end{array}$ & $\begin{array}{l}\text { 1) }-1 \\
\text { 2) }-3\end{array}$ & & $\begin{array}{c}\text { 1) }-1.14 \\
\text { 2) }-4.96^{*}\end{array}$ & $\begin{array}{l}\text { 1) }-2.86^{*} \\
\text { 2) }-5.74^{*}\end{array}$ \\
\hline UR & & $\begin{array}{l}\text { 1) }-1.27 \\
\text { 2) }-3.37\end{array}$ & $\begin{array}{l}\text { 1) }- \text { - } \\
\text { 2) }-2\end{array}$ & .54 & $\begin{array}{l}\text { 1) }-0.62 \\
\text { 2) }-3.03\end{array}$ & $\begin{array}{l}\text { 1) }-1.59 \\
\text { 2) }-3.03\end{array}$ \\
\hline
\end{tabular}

${ }^{\star}$ reject null hypothesis at 0.05 level., N/A not available or not performed, N/C not the case. 
Unit root results for MIN

\begin{tabular}{|c|c|c|c|c|c|c|}
\hline \multicolumn{7}{|c|}{ Panel data Analysis } \\
\hline \multirow[t]{2}{*}{ Variables } & \multicolumn{3}{|c|}{$\begin{array}{l}\text { Unit root test equation includes intercept } \\
\text { H0: the series has unit root }\end{array}$} & \multicolumn{3}{|c|}{$\begin{array}{c}\text { Unit root test equation includes trend } \\
\text { and intercept } \\
\text { H0: the series has unit root }\end{array}$} \\
\hline & IPS & ADF-Fisher & PP-Fisher & IPS & ADF-Fisher & PP-Fisher \\
\hline Ln_GVA & -0.95 & 12.11 & 12.33 & 0.50 & 5.02 & 5.02 \\
\hline$\Delta$ Ln_GVA & $-3.97^{\star}$ & $30.76^{*}$ & $40.21^{*}$ & $-5.12^{\star}$ & $35.96^{*}$ & $35.71^{\star}$ \\
\hline UR & -0.27 & 7.10 & 6.34 & -1.09 & 11.22 & 9.45 \\
\hline$\Delta \mathrm{UR}$ & $-5.72^{\star}$ & $44.92^{\star}$ & $82.54^{\star}$ & $-2.94^{\star}$ & $21.97^{\star}$ & $69.43^{*}$ \\
\hline \multicolumn{7}{|c|}{$\begin{array}{l}\text { Time series analysis by countries } \\
\text { DF-GLS (ERS) (Max lag = 2) H0: series has unit root } \\
\text { Vogelsang (additive outliers) (max lag = 3), } \min (\mathrm{t}) \text { criteria H0: series has unit root }\end{array}$} \\
\hline & & Greece & Italy & & Portugal & Spain \\
\hline Ln_GVA & & $\begin{array}{l}\text { 1) }-1.37 \\
\text { 2) }-3.73\end{array}$ & $\begin{array}{l}\text { 1) }-0 \text {. } \\
\text { 2) }-3 \text {. }\end{array}$ & & $\begin{array}{l}\text { 1) }-1.69 \\
\text { 2) }-3.07\end{array}$ & $\begin{array}{l}\text { 1) }-1.39 \\
\text { 2) }-2.95\end{array}$ \\
\hline UR & & $\begin{array}{l}\text { 1) }-1.30 \\
\text { 2) }-5.08^{*}\end{array}$ & $\begin{array}{l}\text { 1) }-1 \text {. } \\
\text { 2) }-3 \text {. }\end{array}$ & & $\begin{array}{l}\text { 1) }-2.26^{*} \\
\text { 2) }-3.99\end{array}$ & $\begin{array}{l}\text { 1) }-1.29 \\
\text { 2) }-3.28\end{array}$ \\
\hline
\end{tabular}

${ }^{*}$ reject null hypothesis at 0.05 level., N/A not available or not performed, N/C not the case.

Unit root results for TRADE

\begin{tabular}{|c|c|c|c|c|c|c|}
\hline \multicolumn{7}{|c|}{ Panel data Analysis } \\
\hline \multirow[t]{2}{*}{ Variables } & \multicolumn{3}{|c|}{$\begin{array}{l}\text { Unit root test equation includes intercept } \\
\text { H0: the series has unit root }\end{array}$} & \multicolumn{3}{|c|}{$\begin{array}{l}\text { Unit root test equation includes trend } \\
\text { and intercept } \\
\text { H0: the series has unit root }\end{array}$} \\
\hline & IPS & ADF-Fisher & PP-Fisher & IPS & ADF-Fisher & PP-Fisher \\
\hline Ln_GVA & $-2.05^{\star}$ & $16.61^{*}$ & $16.44^{*}$ & 0.23 & 5.95 & 1.41 \\
\hline$\Delta \mathrm{Ln} \_\mathrm{GVA}$ & $-1.93^{*}$ & 15.45 & $15.83^{*}$ & $-2.14^{*}$ & $16.82^{*}$ & 13.07 \\
\hline UR & 0.10 & 7.04 & 2.8 & -0.57 & 9.17 & 2.82 \\
\hline$\Delta \mathrm{UR}$ & $-2.06^{*}$ & $16.88^{*}$ & $17.21^{\star}$ & -1.59 & 13.85 & 9.07 \\
\hline \multicolumn{7}{|c|}{$\begin{array}{l}\text { Time series analysis by countries } \\
\text { DF-GLS (ERS) (Max lag = 2) H0: series has unit root } \\
\text { Vogelsang (additive outliers) }(\max \operatorname{lag}=3), \min (\mathrm{t}) \text { criteria H0: series has unit root }\end{array}$} \\
\hline & & Greece & Italy & Portugal & \begin{tabular}{l|l} 
Spain \\
\end{tabular} & \\
\hline Ln_GVA & & $\begin{array}{l}\text { 1) }-1.54 \\
\text { 2) }-2.58\end{array}$ & $\begin{array}{l}\text { 1) }-0.95 \\
\text { 2) }-3.64\end{array}$ & $\begin{array}{l}\text { 1) }-0.77 \\
\text { 2) }-3.08\end{array}$ & $\begin{array}{l}\text { 1) }-0.7 \\
\text { 2) }-2.8\end{array}$ & \\
\hline UR & & $\begin{array}{l}\text { 1) }-2.11^{\star} \\
\text { 2) }-4.77^{\star}\end{array}$ & $\begin{array}{l}\text { 1) }-0.26 \\
\text { 2) }-4.92^{\star}\end{array}$ & $\begin{array}{l}\text { 1) }-1.54 \\
\text { 2) }-6.27^{\star}\end{array}$ & $\begin{array}{l}\text { 1) }-2 .( \\
\text { 2) }-4 .(\end{array}$ & \\
\hline
\end{tabular}

${ }^{*}$ reject null hypothesis at 0.05 level., N/A not available or not performed, N/C not the case. 
Unit root results for ADM

\begin{tabular}{|c|c|c|c|c|c|c|}
\hline \multicolumn{7}{|c|}{ Panel data Analysis } \\
\hline \multirow[t]{2}{*}{ Variables } & \multicolumn{3}{|c|}{$\begin{array}{l}\text { Unit root test equation includes intercept } \\
\text { H0: the series has unit root }\end{array}$} & \multicolumn{3}{|c|}{$\begin{array}{l}\text { Unit root test equation includes trend } \\
\text { and intercept } \\
\text { H0: the series has unit root }\end{array}$} \\
\hline & IPS & ADF-Fisher & PP-Fisher & IPS & ADF-Fisher & PP-Fisher \\
\hline Ln_GVA & $-2.85^{\star}$ & $22.96^{*}$ & $21.71^{*}$ & 1.26 & 2.12 & 2.53 \\
\hline$\Delta$ Ln_GVA & NC & $\mathrm{NC}$ & $\mathrm{NC}$ & $\mathrm{NC}$ & $\mathrm{NC}$ & $\mathrm{NC}$ \\
\hline UR & 0.03 & 9.38 & 3.03 & -0.35 & 8.87 & 2.46 \\
\hline$\Delta \mathrm{UR}$ & $-3.30^{\star}$ & $25.17^{\star}$ & $25.97^{\star}$ & $\mathrm{NC}$ & $\mathrm{NC}$ & $\mathrm{NC}$ \\
\hline \multicolumn{7}{|c|}{$\begin{array}{l}\text { Time series analysis by countries } \\
\text { DF-GLS (ERS) (Max lag }=2) \text { H0: series has unit root } \\
\text { Vogelsang (additive outliers) }(\max \operatorname{lag}=3), \min (\mathrm{t}) \text { criteria H0: series has unit root }\end{array}$} \\
\hline & & Greece & Italy & Portugal & & ain \\
\hline Ln_GVA & & $\begin{array}{l}\text { 1) }-1.58 \\
\text { 2) }-3.06\end{array}$ & $\begin{array}{l}\text { 1) }-1.68 \\
\text { 2) }-4.03 \\
\end{array}$ & $\begin{array}{l}\text { 1) }-1.45 \\
\text { 2) }-3.91 \\
\end{array}$ & & $\begin{array}{l}-0.85 \\
-2.64\end{array}$ \\
\hline UR & & $\begin{array}{l}\text { 1) }-2.44 \\
\text { 2) }-4.13\end{array}$ & $\begin{array}{c}\text { 1) }-0.01 \\
\text { 2) }-5.60^{*}\end{array}$ & $\begin{array}{c}\text { 1) }-1.50 \\
\text { 2) }-5.99^{*}\end{array}$ & & $\begin{array}{l}2.98^{*} \\
4.65^{*}\end{array}$ \\
\hline
\end{tabular}

${ }^{\star}$ reject null hypothesis at 0.05 level., N/A not available or not performed, N/C not the case. 